\title{
ARTISTIC ACTIVITY AS A COLLABORATION TOOL IN INCLUSIVE SCHOOL CULTURE FORMATION
}

\author{
Aušra Kardašienė \\ Vilnius University Šiauliai Academy, Institute of Education, Lithuania \\ Diana Strakšienè \\ Vilnius University Šiauliai Academy, Institute of Education, Lithuania
}

\begin{abstract}
The article analyses and scientifically evaluates the aspect of collaboration through manifestation of artistic activity as an opportunity to form an inclusive school culture. It is maintained that school culture grounded on the philosophy of inclusive education and enriched with advanced educational processes oriented to artistic/musical activity not only marks the school's uniqueness but also unites and enables the education process participants to collaborate and work together naturally to achieve a shared goal. The main idea of the empirical research presented in the article is to reveal students' attitude towards artistic activities as a means of collaboration, which helps to form the inclusive school culture. The study involved students studying at school and attending a musical activity collective (choir). The research has revealed that in creating the inclusive school culture, artistic activities promote community participants to collaborate, share best practices; they improve the microclimate, ensure the manifestation of the success situation in the educational process, concert activities, and the like. The musical activity grounded on the philosophy of inclusive education becomes an opportunity developing the inclusive school culture that undoubtedly helps to create the society grounded on collaboration and tolerance towards differences, which seeks to envisage every learner's needs and opportunities.
\end{abstract}

Keywords: artistic/musical education, collaboration, inclusive school, school culture.

\section{Introduction}

The change in the global world in recent years promotes to take a new look at the role and future of our state. Today's society is characterized by constant change, global operation, information overload, abundance of technologies, constant knowledge creation and its pragmatic use. Changing processes of the education system inspire striving not only to consistently manage change but also to perceive reality and situations, effectively plan and manage the activities of the school as an organization through collaboration (Kvederaite, 2009). It becomes evident that the educational community must prioritise the ability of collaborative creation and sharing collective knowledge and values in developing the idea of school culture. Such idea unites and enables the 
educational process participants to work together naturally for a common goal, linking the success of all education not only to concrete outcomes but also to the successful activity, the ability to correspond to the spirit of the times and its material manifestation (Survutaite, 2016; Duoblienè, 2018). The school as a community and a place where challenges can be overcome creates opportunities for strengthening collaboration and cohesion of all of its participants. It is a progressive organization that regularly promotes and initiates community events, strengthens its individual members by respecting their peculiarities, specific needs (of gender, cultures, social strata and generations), at the same time encouraging everyone to contribute to the achievement of common goals individually. From this perspective, school culture acquires universal significance in any activity processes of the school as an organization. Thus, it is no coincidence that the issue of school culture arises in various contexts because it is namely culture that determines its members' activeness, meaningful activities, success, and satisfaction - a strong sense of identity. According to the authors (Ainscow, 2007; Spratt, Florian, 2015; Abawi, Carter, Andrews, Conway, 2017; Gruenert, Whitaker, 2017; Watson, Hodges, 2017; Nisser, 2017; Qvortrup \& Qvortrup, 2018; Lakkala, Juškevičienè, Česnavičienè, Poteliūnienė, Ustilaitè, Uusiautti, 2019), particular attention must be paid to every participant in the educational process; i.e., education needs to be personalized, recognizing that people's experiences, needs and strivings differ and that learning takes place in different ways and at different paces. Hence, the vision of the advanced society is associated with the knowledge and development of each of its members' experiences, needs, and abilities. School culture can be the context that is favourable to unfolding of the personality, promotes its creativity, and is measured by a rational, common sense. Such conception of culture is associated with innovations, collaboration, learning from experience according to every person's abilities, interests, and shared goals. Along with the change in the attitude towards children, the activities of students with the dimension of diversity undoubtedly become part of school culture, emphasizing the socially and culturally new model of education - inclusive education, aimed at all learners' active involvement in the learning process.

The analysis of scientific studies reveals the importance of community collaboration in the school development as well as the growing interest in the ideas of inclusive education; however, there is a lack of research highlighting the links between the latter modern educational phenomenon and school culture. The novelty of the study is also reflected in the fact that no works have been detected so far to have been consistently researched forms forming an inclusive school culture artistical/ musical educational processes, encouraging cooperational resolution. In this respect, it is relevant to analyse the settings of inclusive artistic/musical learning, favourable to today's educational reality, 
which are characteristic of the (self-)formation of school culture in the context of collaboration. The article presumes that a particular role in shaping the inclusive school culture falls on music education because according to researchers (Bennis, Goleman, O'Toole, 2008; Samama, 2013; Westerlund, Karlsen, Partti, 2019), this field of education is equated to multicultural cognition grounded on the development of the learner's intellectual abilities, the awakening of the emotional beginning, and the formation of a relationship with oneself and the surrounding world. There is a growing understanding of the importance of music education for students' cognitive, emotional and social development. Considering these arguments, it makes sense to analyse, investigate and scientifically evaluate the role of the artistic activity as a means of forming the inclusive school culture in the context of collaboration.

The object of the research: the artistic activity in the context of collaboration in the inclusive school culture.

The aim of the research: to reveal students' attitude towards the artistic activity as a means of collaboration in the formation of the inclusive school culture.

\section{Research Methodology}

The sample of the research. The study involved 14 gymnasium students. The age of the selected informants varies from 15 to 19 years. The research sample was formed employing the snowball sampling technique (Rupšienè, 2007). The choice of the said method of sampling was determined by the striving to include a maximum variety of learners' teaching/learning experiences in the gymnasium during the research. The gymnasium's collective chosen for investigation is mature by its stage experience, has participated in international competitions and festivals and reached a high level of professionalism that is proved by numerous competitions won by this collective. The collective's leader has accumulated the necessary stage experience and can share reliable information about the phenomenon under study.

Data analysis. The data analysis was performed using the method of qualitative content analysis (Žydžiūnaite,, Sabaliauskas, 2017). The study was conducted by selecting the traditional method of qualitative content analysis based on inductive logic, where categories were derived from data during the analysis, while individual, separate cases illustrating respondents' perceptions and experiences were combined into a single whole. The whole process of the qualitative content analysis took place in three stages: preparation, organization, and data presentation. Specific procedures of the inductive qualitative content analysis were followed (Elo, Kyngäs, 2008): 1) selection of the semantic units of 
Kardašiene \& Strakšienè, 2021. Artistic Activity as a Collaboration Tool in Inclusive School Culture Formation

the analysis, 2) understanding of data and the whole, 3) open coding, 4) creating categories, 5) abstraction, and 6) preparation of conceptual categories.

Table 1 Change in Choristers' Behaviour/Communication while Attending the Collective

\begin{tabular}{|c|c|c|}
\hline Category & Subcategory & Illustrating statement \\
\hline \multirow{4}{*}{$\begin{array}{l}\text { SELF - } \\
\text { AWAREN } \\
\quad \text { ESS }\end{array}$} & $\begin{array}{l}\text { Perception of } \\
\text { one's } \\
\text { individuality }\end{array}$ & $\begin{array}{l}\text { "At first I used to feel timid, you would sit down while } \\
\text { nothing was happening and at some moment, there was such } \\
\text { break when you start being yourself, feeling very good and } \\
\text { you can joke freely and... all those friendships are formed, } \\
\text { then everything changes radically, all behaviour." A8. }\end{array}$ \\
\hline & $\begin{array}{l}\text { Experience } \\
\text { by observing } \\
\text { others }\end{array}$ & $\begin{array}{l}\text { "... we became very, very close; maybe joint events, joint } \\
\text { trips brought us closer, maybe in the beginning, those } \\
\text { relationships were slightly colder, you could feel that } \\
\text { boundary where the ensemble was and where the choir was; } \\
\text { and now, in the last year, that communication changed very } \\
\text { very much, it became much warmer." A9 }\end{array}$ \\
\hline & $\begin{array}{l}\text { Personal } \\
\text { initiatives in } \\
\text { encouraging } \\
\text { other } \\
\text { choristers }\end{array}$ & $\begin{array}{l}\text { "The most important thing is that she took courage from us } \\
\text { and came to the celebration of the first of September without } \\
\text { a wig and looked very beautiful and just showed what inner } \\
\text { strength she herself had, what self-confidence she had, and it } \\
\text { seems to me that the choir and the collective just encouraged } \\
\text { her to look at herself, she took from us, from the choir that } \\
\text { strength, and now she doesn't wear the wig. At all."A8 }\end{array}$ \\
\hline & $\begin{array}{l}\text { The } \\
\text { collective - } \\
\text { bullying } \\
\text { prevention }\end{array}$ & $\begin{array}{l}\text { "On the first day of September, I wrote to the choir group } \\
\text { that if strangers dared say something in front of her eyes, } \\
\text { she had to know that } 50 \text { people were guarding her." A9 }\end{array}$ \\
\hline
\end{tabular}

Research results. An important role in creating the inclusive school culture is played by the students attending artistic activity classes (in this case, the school choir). Here, every student's abilities, needs and opportunities are noticed; while fostering high expectations for each student's achievements, collaboration and teamwork as well as personal continuous professional development take place, taking responsibility for lifelong learning; friends are found; emotional connections are established; and many pleasant moments are experienced. Enhanced by believing and trusting, communication/collaboration enable to move towards the goal faster - achieve good artistic results and versatile personality development. To find out how communication and behaviour of choristers attending the collective change, what unites them and enables them to collaborate and work together naturally to achieve the common goal, and what success situations reflecting inclusive education trends choristers experience, a qualitative focus group study involving gymnasium students was conducted. During the study, students' experiences in the gymnasium collective 
were analysed. Analysing the choristers' answers to the research question, asking the informants to share their experiences of how their communication and collaboration was changing while attending the collective, a dimension describing the experiences lived by choristers was singled out; i.e., change in the choristers' behaviour/communication/collaboration while attending the collective (Table 1).

Every person is forced to communicate and at work, to collaborate - even the greatest individualists have to participate in a team "game" in one way or another way, seeking common goals. According to D. Coyle, the foundation of successful teamwork is the culture of work and collaboration (Coyle, 2018). Analysing choristers' self-identification in the context of change in behaviour/communication while attending the collective, four subcategories confirming the category Self-awareness were identified. The first subcategory of establishing one's identity - Perception of one's individuality - is outlined as follows: in the first rehearsal, one perceives oneself as a person distinguishing himself/herself by individuality but lacking confidence in one's abilities ("At first I felt quite timid to sing solo in front of my colleagues or otherwise; I think I am such a newcomer here, so why should I show here anything, I won't jump out here when all are looking, but over time, I felt very welcomed, I felt as if I really were a member of the team and that I could unfold myself fully and be myself; therefore, I will always be grateful that I was admitted and was allowed to be the way I am (A4)"). Other informants' speeches highlighted that students identified choir rehearsals with a usual lesson until feeling unfettered, they could be truly themselves. Comparing their and other colleagues' experiences in first choir rehearsals, informants notice that all live new experiences. All students come to the choir with different abilities; therefore, many factors will determine how the collective will unite into one whole and follow the established rules. ("I think that everyone felt uncomfortable in that very beginning; just you come to a new place, new people, you don't know how you will be received, you don't know if you will fit in that collective, maybe you won't even like it at all, maybe you just won't want to go there. But after a while, you realize whether you want to be here or not. A lot depends on people as well as on the leader and the atmosphere itself, whether your behaviour will change or not (A5)".)

Research participants shared their thoughts on the change in their behaviour and communication with new choristers (subcategory Experience by observing others), who later turned into a pleasant surprise for them. Informants note that engaging in choral activities promotes young people to unfold themselves faster and discover their new talents ("When I was still in the old ensemble, there were old members, and when new ones came, I remember A4 and A6 very well, when they were very modest, communicated little, maybe they were shy to sing, but now, when you see what people unfolded when they got 
involved in the collective, it's a lot of fun to see that during that time we've spent together, people showed their talent so greatly, what they are able to do (A5)"). Rehearsals, concerts of the ensemble and choir, joint trips of the two groups not only give a sense of pleasure, enrich the singers and listeners themselves, raise their mood, but also melt the boundary between more talented students and those with less musical abilities. Informants note that musical activities bring together and promote communication/collaboration with each other ("As to communication between the choir and the ensemble, I noticed that in the last years of my participation in this activity, the choir and the ensemble became very very close to each other, we started to collaborate, seek common goals (A9)"). Friendliness, communication and collaboration, equality, trust, partnership relationships between the leader and the choristers, hearing and listening carefully, a sense of security, the opportunity to realize oneself and be noticed for everyone respond to the idea of inclusion ("Over time, people unfolded themselves a lot and were no longer so shy, and I notice that over time, people communicate more bravely, then they feel better in the collective, then they sing more freely, that also contributes to it; express their opinion already, at first mostly sit timidly, look around. And then, already over time, all unfold themselves a lot (A6)").

Culture is not what you are saying but what you are doing. Therefore, another distinguished subcategory - Personal initiatives in encouraging other choristers - reveals that attending the collective, choristers come not only to improve their abilities and establish friendly relationships but they also notice those who are unsuccessful in something, try to advise and encourage them, this way reminding them that you are not alone, you are a part of the collective, and we care a lot. When the person feels safe and needed, he/she will be an active member of the community, and you will no longer need to waste energy to overcome some fears. ("I'm that kind of person who really sincerely tries one's hardest; if I see that the person is timid, I try to communicate or say something so that he/she feels a little more like in the collective, so that he/she doesn't feel so alone (A6)". "This relationship is reflected in our performances, makes our performances so sincere and our performance touches the listener as well (A2)").

Singing not only performs a strong social function - singers also experience social approval, belonging, and acceptance in group participation (Parker, 2017); therefore, no doubt a strong relationship established between collective members can certainly work wonders. Informants gladly shared a memory that proves once again that the unity of the collective can give a disappointed person a lot of courage ("There is a girl in our choir, who wears a wig for a very large part of her life, because she has a genetic disorder when the hair on her head does not grow and, well, she was afraid sometimes when, say, 
someone played up and wanted to pull a plait, she would be very much afraid so that someone didn't pull her wig. When there was a choir camp at the end of the summer, she told us on the very last day that she was actually wearing the wig all the time. I asked her to show how she looked without it. And she took off that wig and we all, no one started laughing or something, but we all said like WOW, you have to go without the wig, some day you really have to go without the wig (A8)". "She looked so good! And most importantly, one could feel that she started to be self-confident, which is very nice to watch (A6)".

The way we behave, communicate, things we believe in, our attitudes or values broadcasted to people around us undoubtedly determine our role in the school community. The term denoting negative phenomena taking place in our society - bullying - recently has been increasingly used in everyday life too. Bullying undoubtedly affects the sense of security of school community members. As we recognize this phenomenon increasingly often, there is hope to reduce its scope. The art collective can become one of the measures preventing bullying. The participants of the research regret about the current situation in educational institutions in general, but bravely defend their collective members as shown by the subcategory The collective - bullying prevention: ("Others really stared at her but not the choristers. I think such bullying happens and will always be. "On the first day of September, I wrote to the choir group that if strangers dared say something in front of her eyes, she had to know that 50 people were guarding her (A9)").

Analysing choristers' answers to the research question asking informants to share them of success situations experienced while collaborating in artistic collective activities, two categories were distinguished: Communication/ collaboration (with three distinguished subcategories) and Success situation while collaborating (with two distinguished subcategories). The dimension describing choristers' success situations in terms of collaboration is presented in Table 2.

Table 2 Choristers' Success Situations in the Aspect of Collaboration

\begin{tabular}{|c|c|c|}
\hline Category & Subcategory & Illustrating statement \\
\hline \multirow{2}{*}{$\begin{array}{l}\text { COMMUNI- } \\
\text { CATION / } \\
\text { COLLABO- } \\
\text { RATION }\end{array}$} & $\begin{array}{l}\text { Support from the } \\
\text { leader, parents, } \\
\text { subject teachers, } \\
\text { administration }\end{array}$ & $\begin{array}{l}\text { "...You still focus on the gymnasium's public life. } \\
\text { You stand on the stage, people see you, parents see } \\
\text { what you are doing, what you are like, what you have } \\
\text { become."A8 }\end{array}$ \\
\hline & $\begin{array}{l}\text { Collaborative } \\
\text { language } \\
\text { learning }\end{array}$ & $\begin{array}{l}\text { "The German teacher encourages us to take part in } \\
\text { German song competitions, she finds songs for us, } \\
\text { our leader arranges them and this is a lot of fun that } \\
\text { the teacher himself wants to get involved and takes } \\
\text { initiative encouraging us to participate and maybe } \\
\text { deepen the knowledge of the German language."A5 }\end{array}$ \\
\hline
\end{tabular}


Kardašienè \& Strakšienè, 2021. Artistic Activity as a Collaboration Tool in Inclusive School Culture Formation

\begin{tabular}{|c|c|c|}
\hline & $\begin{array}{l}\text { Open lessons, } \\
\text { dissemination }\end{array}$ & $\begin{array}{l}\text { "There was an open lesson, teachers had come from } \\
\text { another city and we then had such a lesson there, the } \\
\text { lesson of music and German." A8 }\end{array}$ \\
\hline \multirow[t]{2}{*}{$\begin{array}{c}\text { SUCCESS } \\
\text { SITUATION } \\
\text { WHILE } \\
\text { COLLABO- } \\
\text { RATING }\end{array}$} & $\begin{array}{l}\text { Evaluation of } \\
\text { acquired } \\
\text { experience }\end{array}$ & $\begin{array}{l}\text { "How much success I experienced and how much of } \\
\text { it I felt then that really I was so happy that I have } \\
\text { such people in my collective, who support me. It } \\
\text { doesn't take even some three days when someone } \\
\text { from the collective writes to me "How are you } \\
\text { doing?", this is the biggest success for me. It is really } \\
\text { inconceivable for me how people who are linked by } \\
\text { music can feel each other so much, support each } \\
\text { other, so this was the most successful moment for me } \\
\text { here". A6 }\end{array}$ \\
\hline & $\begin{array}{c}\text { Joy in coping } \\
\text { with difficulties }\end{array}$ & $\begin{array}{l}\text { "I think that the result is so gratifying because so } \\
\text { much work is put into it. This is why work is more } \\
\text { important, the whole process itself. And the outcome } \\
\text { is motivation for the next process." A6 }\end{array}$ \\
\hline
\end{tabular}

Analysing the education documents on quality education issues, it is emphasised that the society needs to create more inclusive educational institutions, while the role of parental involvement in this development is essential. One of the cornerstones of school activities is a collaboration-based relationships encompassing diverse partnership, involving every member of the community (European Commission, 2017). The family and the school are two most important institutions for the child's education; thus, school-family collaboration undoubtedly becomes an important condition for successful education. It is highly important that collaboration is grounded on mutual trust so that parents feel needed for the school. Parental involvement in school life is not easy and simple. At this point, a big role can be played by musical activities. Music making highlights collaboration not only between parents, family members but also between the participants of educational processes - teachers, the leader, and administration. According to informants, it is very important that their participation in the choir activities is supported by the whole community of the gymnasium (subcategory Support from the leader, parents, subject teachers, administration) "Everyone's support is very important. Support, indeed, if people tell you that they like what you are doing, this is a kind of incentive (A8)", but what informants distinguish most is the role of parents in their lives ("It is very important to have that feedback from the environment. Besides, parents, also, let's say, my mom sometimes, when something is recorded, she has to watch that record on the phone five times in the evening. And it's quite important that people really like what we are doing. It is not only that we like it, but also that people like the result (A8)"). Based on St. Gruenert, T. Whitaker, teacher-student communication and collaboration should be accompanied by 
mutual respect, tolerance, understanding because working together in a favourable microclimate allows for improvement by learning from each other (Gruenert, Whitaker, 2017). Research participants' experiences tell that it is important for choristers to feel valued, respected; they also indicate that teachers and administration not only attend their concerts but also incidentally get into a conversation in the school corridor, classroom ("The authorities also smile, come, speak, like our collective and activities a lot, support a lot. When there is something in the lessons about art, about music, then, yes, already A8, the musician here (ha ha ha). Very often also just praise, support (A8)”).

Performing, concert activities promote both students and teachers to work together, consult each other, share best practices, and this in itself is a step towards the formation of the inclusive school culture (Nisser, 2017). The subcategory distinguished while following this approach is Collaborative Language Learning: "It is fun when, for example, even teachers get involved in such collaboration. A good example of this is our German teacher (A4)". Informants note that learning a foreign language is useful even if it you are not learning it during the lessons ("Interestingly, almost half of us singing are not learning German (ha ha ha). But, anyway, they take interest and there is certain knowledge of the language, such lessons are valuable; when singing in different languages that you know, anyway, certain words, certain phrases stick in your memory, and then you just develop your mind (A8)"). Research participants also notice that such collaboration not only gives them positive emotions when learning the new language but also provides them with the opportunity to participate in competitions ("Both teachers consult on how it would be better and just that support from both sides is perfect (A5)"). Another informant notes that competitions pose certain challenges that teach to be prepared for various unexpected challenges in life ("When I came to the ensemble, in one year, I was given a task to learn a short solo part of a German song with the ensemble, then, we went to a national competition. After that competition, next year, I myself offered a song that I wanted to learn and the teacher wrote an arrangement straightaway for all the song for the ensemble. Because we have very strong assistance - the German teacher herself and our leader - the fact that we didn't know the German language at all and the competition went really well, such an overall result really brought joy (A9)").

School culture is also created by its relationships and collaboration with other educational institutions (OECD, 2016). Collaborating with educational institutions, teachers share experiences, novelties, respect other opinions, participate in various joint activities: events, conferences, disseminate project results, and deliver open lessons (Hammersley, 2001; Ainscow, Booth, 2017). Informants note that such types of activities force them to gear up, concentrate, realize themselves (subcategory Open lessons, dissemination: "They watched 
the artistic activity, how it is performed. And we performed and they evaluated it very well; they said that there children could realize themselves, they could sing; so I think that such communication with the representatives of education is also a certain incentive to improve oneself (A5)").

The team works well when plans are discussed at the beginning of the school year, a general repertoire of musical pieces is set up, the leader collaborates with choristers, when activities are constantly reflected, choristers' progress is assessed, everyone is noticed, the focus is not solely on the result but also on the process, tasks are shared, when all these facts are combined by an extraordinary experience of the success situation. Informants' experiences that have shown up (see Table 2, category Success situation while collaborating) revealed the fact that the most important goal was not the result but the process (subcategory Evaluation of acquired experience "I think that the result is so gratifying because so much work is put into it. This is why work is more important, the whole process itself. And the outcome is motivation for the next process (A6)"). Research participants give a positive feedback on the experience gained while attending the collective. Here they not only develop vocal abilities but also form as personalities, find real friends, and call the collective a family. For this to happen, everyone undoubtedly needs to feel a strong link, a selfless friendship, and trust that is built based on values ("With this collective we have the opportunity to experience what you may not experience every day. For example, the Lithuanian National Opera and Ballet Theater. WOW. Just, well, you never think you'll spend as many as several days here. It's just even hard to describe what it feels like (A4)"). Success situations experienced together along with a sense of community that has matured in the collective for a long time remain as a wonderful memory ("True success has a slightly different meaning for me. On the last day at the camp, when we had to say goodbye to everyone, when I thought we wouldn't see each other, then I felt how happy I was to have such people in my collective... (A6)").

According to D. Coyle, three core skills are required for a group of people to feel that they work towards a shared goal. These are creation of a safe environment, perception of shared vulnerability, and a sense of purposeful action (Coyle, 2018). By singing together, the choir members learned to work as one team and pursue the common goal that promoted everyone to make commitments and participate in rehearsals. Research participants note that they were not at all intimidated by long rehearsals and joint work as they were all brought together by a shared goal (see Table 2, subcategory Joy in coping with difficulties). In their opinion, success as unification and communion is the most difficult musical piece of the competition, which was selected by drawing lots. This proves that choristers feel safe being together, are well prepared for the competition in their joint activities ("About the Song Festival. When you're 
working a lot, when you're learning those songs a good year, actually one year, when you're putting a lot of work into it, in fact we really sincerely tried our best for those musical pieces; some were those which we liked more, some, those which we didn't like at all, and, one of the success factors was that we drew lots and got our favourite musical piece (laughs). That was our success (A8)"). Communication and collaboration strengthen interrelationships because people's inner values are similar, only emotions or people's personal problems do not allow many of them to see them. Enhanced by believing and trusting, communication/collaboration enable to move towards the goal faster - achieve good artistic results and versatile personality development. Thus, talking about preparation for competitions, performances, etc., informants put emphasis not only on the importance of the process but also distinguish one very important aspect - character formation ("The process is more important. Because it forms your character. Yes, the result is important. It motivates, encourages to gear up and so on, but during the process, you yourself are improving, learning to learn, you are in a good, cosy environment and for your own sake, let's say, your wellbeing becomes better. For that reason I think the process is more important (A8)"). Joint work makes you feel appreciated ("When you put a lot of effort into it and you see the result that you're really appreciated, you really feel in euphoria, you really feel uplifted, and you feel that the work wasn't in vain (A8)").

In summary, it can be stated that research participants single out the ability to communicate as the most important of all human traits. Collaborative communication is defined as the interaction between people, during which they exchange information and create a respective emotional connection. Communication helps to better meet various social needs such as belonging to a certain group (choir, orchestra, team, religion, club, etc.), support (students support each other, the teacher supports his students; parents, children; leaders, subordinates), attachment (the need to care for others and feel the care of others), and etc. All research participants unanimously state that the most important part in musical activities is joint work, in other words, collaboration, which enables to reveal strong partnership relationships and the opportunity for every member to realize his/her contribution. Students' experiences identified in the conducted research clearly demonstrated that the foundation of school activities - collaborative relationships, namely, student-teacher partnership, teacher partnership, student-parent-teacher partnership through musical activities - responded to the idea of the inclusive school culture. 
Kardašiene \& Strakšiene, 2021. Artistic Activity as a Collaboration Tool in Inclusive School Culture Formation

\section{Conclusions}

The conducted analysis of students' experiences reveals that artistic/musical activities are more identified not as a part of the educational process but as striving to unfold oneself, create and express oneself in the course of learning through collaboration.

The analysis of the research revealed the most important segments named by learners, which influenced successful manifestation of collaboration in the musical collective. Informants indicated that artistic/musical/collective activities undoubtedly helped to perceive their individuality, perception of identity, communication experience, tolerance for different students, personal initiatives, and even bullying prevention. In the opinion of most informants, interrelationships between the collective's members, which are revealed by emphasizing such internal factors as mutual respect and the sense of community, are very important in the art collective. Students are convinced that selfconfidence is essential to achieve common results.

The analysis of the research also significantly revealed the role of collaboration of all participants of the educational process (parents, teachers, administration), which directly determines the manifestation of the success situation of learners' artistic activities. Informants' experiences indicate particular importance of parental support promoting learners' high self-esteem, while integration of artistic type activities in collaboration with subject teachers inspires students to gear up, concentrate, bravely realize themselves and develop a wide range of competencies; e.g., learn the foreign language, and the like. Collegial communication with teachers and school administration is especially useful for participation in various school events, open lessons, and implementation of projects. It is evident that successful integration of the art collective into various types of school events is in itself a step towards the formation of the inclusive school culture.

The performed analysis of students' experiences reveals that artistic/musical activities are significant in creating the school for everyone because they allow to notice every learner's abilities, needs and opportunities, students find friends, form emotional relationships, experience success situations, and live many pleasant moments. By collaborating closely in artistic activities, the members of the collective evidently enhance their tolerance for a different member of the community. The artistic activity not only creates favourable interpersonal relationships, enriches singers and listeners themselves but also becomes a great tool for the formation of the inclusive school culture. 


\section{References}

Abawi, L., Carter, S., Andrews, D., Conway, J. (2017). Inclusive Schoolwide Pedagogical Principles: Cultural Indicators in Action. In O. Bernard Cavero, N. Llevot-Calvet (Eds.). New Pedagogical Challenges in the 21st Century-Contributions of Research in Education (p. 33-55). London: IntechOpen.

Ainscow, M. (2007). Education for All: Making it Happen. Support for learning, 10 (4), 147-155.

Ainscow, M., Booth, T. (2017). Index für Inklusion. Weinheim.

Bennis, W., Goleman, D., O'Toole, J. (2008). Transparency: How Leaders Create a Culture of Candor. San Francisco: John Wiley \& Sons.

Coyle, D. (2018). The Culture Code: The Secrets of Highly Successful Groups. New York.

Duoblienè, L. (2018). Dekoduoti. Monografija. Vilnius: Vilniaus universiteto leidykla.

Elo, S., Kyngäs, H. (2008). The qualitative content analysis. Journal of Advanced Nursing, 62(1), 107-15.

European Commission. (2017). School development and excellent teaching for a great start in life. Retrieved from https://www.schooleducationgateway.eu/en/pub/resources/ publications/school-development-and-excelle.htm

Gruenert, S., Whitaker, T. (2017). School Culture Recharged: Strategies to Energize You Staff and Culture. Alexandria, Virginia: ASCD.

Hammersley, M. (2001). Some questions about evidence-based practice in education. University of Leeds, England.

Kvederaitè, N. (2009). Šiuolaikinès mokyklos kaip besimokančios organizacijos bruožu raiška personalo savivaldaus mokymosi sklaidos procesuose. (Unpublished doctoral dissertation). Šiaulių universitetas, Šiauliai.

Lakkala, S., Juškevičienè, A., Česnavičienè, J., Poteliūnienè, S., Ustilaitè, S., Uusiautti, S. (2019). Implementing Inclusive Education in Lithuania: What are the main Challenges according to Teachers' Experiences? Acta Paedagogica Vilnensia, 43, 37-56.

Nisser, D. von A. (2017). Can collaborative consultation, based on communicative theory, promote an inclusive school culture? Issues in Educational Research, 27(4), 874-891.

OECD. (2016). What makes a school a learning organisation? A guide for policy makers, school leaders and teachers. Organisation for Economic Co-operation and Development. Retrieved from https://www.oecd.org/education/school/school-learning-organisation.pdf

Parker, E.C. (2017). A Grounded Theory of Adolescent High School Women's Choir Singers' Process of Social Identity Development. Journal of Research in Music Education, 65(4), 439-460. DOI: https://doi.org/10.1177\%2F0022429417743478

Qvortrup, A. \& Qvortrup, L. (2018). Inclusion: Dimensions of inclusion in education. International Journal of Inclusive Education, 22(7), 803-817. DOI: https:/doi.org/ 10.1080/13603116.2017.1412506

Qvortrup, L. (2007). Kokybinio tyrimo duomenu rinkimo metodologija. Klaipėda: Klaipėdos universiteto leidykla.

Samama, L. (2013). Creative Music Education: Theory and Practice. European Perspectives on Music Education, 2, 77-86.

Spratt, J., Florian, L. (2015). Inclusive pedagogy: From learning to action. Supporting each individual in the context of 'everybody'. Teaching and Teacher Education, 49, 89-96.

Survutaitè, D. (2016). Mokyklos kultūros raiška. Monografija. Vilnius. Lietuvos edukologijos universiteto leidykla. 
Kardašienè \& Strakšienè, 2021. Artistic Activity as a Collaboration Tool in Inclusive School Culture Formation

Watson, M., Hodges, J. (2017). School Climate and the CCRPI. Georgia Department of Education. Retrieved from https://slideplayer.com/slide/12161852/

Westerlund, H.M., Karlsen, S., Partti, H. (Eds.). (2019). Visions for Intercultural Music Teacher Education. Switzerland: Springer.

Žydžiūnaite, V., Sabaliauskas, S. (2017). Kokybiniai tyrimai: principai ir metodai. Vadovèlis socialinių mokslų studijų programų studentams. Vilnius. 